\title{
Capital Structure Theories and Firm's Value-Evidence from Bursa Malaysia Construction Sector
}

\author{
Abdul Razak Abdul Hadi ${ }^{1}$, Nur Farah Nadiah Md Lazim ${ }^{1} \&$ Tahir Iqbal ${ }^{1}$ \\ ${ }^{1}$ Unikl Business School, University of Kuala Lumpur, Malaysia \\ Correspondence: Abdul Razak Abdul Hadi, Unikl Business School, University of Kuala Lumpur, Malaysia. \\ E-mail: abdrazak@unikl.edu.my
}

Received: April 20, 2017

Accepted: July 23, 2017

Online Published: August 12, 2017

doi:10.5539/ijbm.v12n9p163

URL: https://doi.org/10.5539/ijbm.v12n9p163

\begin{abstract}
This paper examines the relevance of Capital Structure theories to the performance of construction firms listed at Bursa Malaysia. Within the framework of Modigliani-Miller and Trade-Off theories, this paper uses Generalized Method of Moments as an estimation model employing yearly panel data over the observed period from 2010 through 2015. The test results from GMM indicate that earnings per share (EPS), dividend per share (DPS) and debt-equity ratio (D/E) have no significant relationship with firm's value as represented by market price per share (MPPS). Even though the findings are rather shocking, one must admit there is an absence of Modigliani-Miller and Trade-Off theories in those construction firms at Bursa Malaysia. Obviously, this is an indication that the efficient market hypothesis prevails to a certain level at Bursa Malaysia.
\end{abstract}

Keywords: modigliani-miller theory; trade-off theory; generalized method of moments; panel data analysis; efficient market hypothesis

\section{Introduction}

Malaysia is a middle-income country which has one of the highest standards of living in South East Asia, largely because of its expanding industrial sector. The Malaysian economy is an open economy where the economic activities involve both domestic community and the international community. Malaysia has a fast growing economy as the country transformed itself since the 1970's from a producer of raw materials into an emerging multi-sector economy due to the Asian financial crisis during year 1997-1998. In year 2015, as a major producer and exporter of crude oil, natural gas, and palm oil, Malaysia's economy was bound to be buffeted by the plunge in demand and prices for hydrocarbons and other commodities. Net external demand dragged down Gross Domestic Product growth in the first half of 2015. As such, during third quarter of 2015, Malaysia's currency has shown the worst performer against the dollar in Asia. Malaysia has become the worst performer among 11 major Asian currencies tracked by Bloomberg. This situation has certain effect towards the concerns among foreign investors to pull out their money and invest their funding in other countries. Prospects for weaker growth threaten to add to the gloom.

The above situation becomes a great challenge to most of the companies in Malaysia on how to sustain their businesses especially in maintaining the cost of financing at the lowest possible level. The cost of financing has become one of the main issues in business activities as it could lead to the increase in overall costs of doing business if it is not being well considered. Thus, it requires the business owner to systematically analyze the right combination of portfolio financing. The well diversified portfolio of financing will be able to minimize the costs involved in business operation and at the same time leading towards maximizing the wealth of the shareholders and company's value. This paper is organized as follows: the next section provides problem statement and literature review. The following section describes the data and methodology used. Finally, the last section provides the empirical findings and concludes the discussion.

\section{Problem Statement}

Capital structure is considered as one of the important elements that requires careful consideration as it could contribute significantly to business performance. The structure of the sources of capital need to be determined in strategic manner in order to minimize the overall cost of financing as well as maximizing the wealth of the shareholders. In other words, the issue of optimal capital structure is very crucial to be determined as it could 
leads to positive impact particularly towards lowering the cost of capital and enable the firm to achieve maximum return with certain acceptable risk level. However, wrongly combined sources of capital could also result in negative impacts as each of sources of capital has its own advantages and disadvantages which requires well balanced combination of the portfolio financing.

In relation to that matter, several studies have tested the hypothesis of finding relationship between characteristics of capital structure and performance. However, few studies have been conducted in the context of companies particularly in construction sector as categorized by Bursa Malaysia. It is indeed important to examine the characteristics and the structures of the capital financing as applied by companies in Construction sector. Generally, companies in different sectors are expected to have different characteristics and structures with regards the capital financing as they have different risk background. Therefore, this paper examine the issue of companies' performance in relation to the application of different combination of capital structure financing among companies in construction sector as listed at Bursa Malaysia.

\section{Literature Review}

There are several significant theories of capital structure in financial management have emerged (Kovenock and Phillips, 1995; Kovenock and Phillips, 1997). The Traditional Theory of Capital structure tells us that wealth is not just created through investments in assets that yield positive return on investment, purchasing those assets with an optimal blend of equity and debt is just as important. This theory believes that when the Weighted Average Cost of Capital (WACC) is minimized, thus the market value of assets are maximized, an optimal structure of capital exists. In sum it says that a firm's value increases to a certain level of debt capital, after which it tends to remain constant and eventually begins to decrease. The modern theory of capital structure began with the celebrated paper of Modigliani and Miller. A firm's capital structure is the relative proportions of debt, equity, and other securities in the total financing of its assets. A business needs to plan its capital structure to optimize the application of the funds and also to be able to adjust easily to the changing environments. From their analysis, they have pointed the direction that such theories must take that capital-structure irrelevance proposition. Essentially, they hypothesized that in perfect markets, it does not matter what capital structure a company uses to finance its operations. They theorized that the market value of a firm is determined by its earning power and by the risk of its underlying assets, and that its value is independent of the way it chooses to finance its investments or distribute dividends. The basic M\&M proposition is based on the key assumptions; (1) No taxes (2) No transaction costs (3) No bankruptcy costs (4) Equivalence in borrowing costs for both companies and investors (5) Symmetry of market information, meaning companies and investors have the same information (6) No effect of debt on a company's earnings before interest and taxes.

In addition, another theory of capital structure that very much relates with the theory proposed by Modigliani and Miller is the trade-off theory. The trade-off theory of capital structure refers to the idea that a company chooses how much debt finance and how much equity finance to use by balancing the costs and benefits. This theory is often set up as a competitor theory to the pecking order theory of capital structure. The term trade-off theory is commonly used to describe a group of associated theories. In all these theories, a decision maker examines the different costs and advantages of alternative leverage plans. The trade-off theory assumes that you can get benefits to leverage within a capital structure until the optimum capital structure is achieved. The theory acknowledges the tax advantage from interest payments. This theory mainly refers to the two concepts; cost of financial distress, and agency costs. A major objective of the trade-off theory is to explain the fact that businesses generally are funded partially with debt and partially with equity.

The relationship between capital structure and company performance is still debatable as many studies which have been conducted revealed various findings. Some of the studies (Krishnan and Moyer, 1997; Zeitun and Tian, 2007) were significantly found out that there were negative relationship between leverage and the firm's performance. The findings with regard the negative relationship between firm's performance and financial leverage from the capital structure were also been identified in several countries as conducted by the researchers (Brigham \& Gapenski, 1996; Majumdar and Chhibber, 1997; Rao, Al-Yahyaee and Syed, 2007). Specifically, Gleason, Mathur and Mathur (2000) have found out that the same findings with regard the negative relationship between firm's performance and types of combination in capital structure. In addition, the issue of the relationship between the firm's performance and different combination in capital structure has also been analyzed in relation to the changes in economic condition especially during Asian financial crisis (Tan, 2012). The study has been conducted and the finding revealed that the negative relationship between the firm's performance and the financial risk from using leverage in financing has been magnified negatively by the financial crisis. 
However, there are many studies which have been conducted and the findings revealed different direction of the relationship between the firm's performance and financial leverage from the capital structure. Most of the studies found out that financial leverage would contribute positively towards increasing the performance of the firms as reflected in improving in the productivity level, enhancing the profitability as well as prospering the EPS value (Huyghebaert, 2006; Titman \& Wessels, 1998; Myers, 2001; Ross, 1977; Noe, 1988). Most of the previous studies have similar findings in confirming the results that value of firms have positively influenced by certain combination of capital structure which closer to the optimum level category (Maksimovic, Stomper and Zechner, 1999; Barclay, Smith and Watts, 1995). Generally, an optimum capital structure with certain amount of leverage financing will enable the firm to minimize the overall cost of financing as well as maximizing the portfolio return from business investment activities (Hadlock \& James, 2002; Corriceli, Driffield, Pal, and Roland,2011). Other researchers have also supported the findings from the studies as debt financing has positive influenced in increasing the firm's value as well as profitability which directly reflect the issue of strong establishment in financial sustainability and better position in maintaining the stability of growth in productivity (Roden and Lewellen, 1995; Sharma, 2006; Ehrhardt and Brigham, 2006)

\section{DATA}

This paper focuses on companies in the construction industry that are listed in Bursa Malaysia. For the analysis, the data were extracted from Stock Performance Guide Handbook, published by Dynaquest. To analyze all the companies in the construction industry, annual data from 2010-2015 were chosen. The main measures that are analyzed in this study are the firm's value, profits, leverage ratio and dividend per share. In order to analyze the panel data, the SAS program is employed.

Below are the companies which have been identified for further analysis:

Table 1

\begin{tabular}{lll}
\hline NO & COMPANY NAME & PRODUCT \\
\hline 1 & AHMAD ZAKI RESOURCES BHD & Construction \\
2 & BENALEC HOLDINGS BHD & Construction \\
3 & BREM HOLDINGS BHD & Construction \\
4 & CREST BUILDER HOLDINGS BHD & Construction \\
5 & EKOVEST BHD & Construction \\
6 & GADANG HOLDINGS BHD & Construction \\
7 & GAMUDA BHD & Construction \\
8 & IJM CORPORATION BHD & Construction \\
9 & KIMLUN CORPORATION BHD & Construction \\
10 & MELATI EHSAN HOLDINGS BHD & Construction \\
11 & MITRAJAYA HOLDINGS BHD & Construction \\
12 & MUHIBBAHENGINEERING (M) BHD & Construction \\
13 & PROTASCO BHD & Construction \\
14 & WCT HOLDINGS BHD & Construction \\
\hline
\end{tabular}

\section{Methodology}

Generalized Method of Moments (GMM) is deployed in testing the determinants of firm's value and their relation with the firm's closing share price. This method provides the panel data with efficient econometric estimators. GMM is an efficient test and tool that can reduce and ease endogeneity problem. Endogeneity is the correlation between the parameters or variables with the error term. This test controls the endogeneity problem by employing unobservable shocks in the cross-sectional component. The research instruments used in this study involve diagnostic tests for GMM validity which are tests of the non- existence of serial correlation of the error terms using the first and second order serial correlation, test for exogeneity of instruments that ensures the consistency of estimates using the Sargan tests. This test is also employed to find out the relation between capital structure determinants and debt equity ratio (D/E). The research framework of the GMM test is shown in Figure 1 below. It is developed to test the determinants of capital structure. To depend on the GMM results, different diagnostic tests are conducted. Sargan test is employed to measure the exogeneity and validity of instruments, while the serial correlation is examined by Autocorrelation test. The panel data increases the number of observations. This set improves efficiency by reducing the multicollinearity problem and increasing the degree of freedom between the 
explanatory variables. Firms are different in their capital structure choice. Cross-sectional data do not cope with this problem. Thus, panel data approach has the advantage of solving the unobserved firm-specific effects. Moreover, compared to cross-sectional data, choosing variables and instruments is easy and more flexible. The endogeneity problem is one of the factors that support the implementation of GMM. Observable as well as unobservable shocks affect corporate capital structure decisions and firm-specific characteristics.

The GMM research framework process is summarized by the following steps. It starts with the diagnostic tests, then to the main research method of GMM, a method that alleviates the deformation caused by fixed effects, simultaneity and endogeneity. The study applied the GMM on a panel data that considers both dimensions of cross-sectional and time-series estimates. The GMM model structure is discussed in the following paragraphs:

Consider the Single Equation Linear GMM as:

$$
\mathrm{Y}_{\mathrm{t}}=\mathrm{zt} \delta 0+\varepsilon_{\mathrm{t}}, \mathrm{t}=1, \ldots, \mathrm{n} \ldots \ldots \ldots
$$

Where $\mathrm{z}_{\mathrm{t}}$ is an $\mathrm{L} \times 1$ vector of explanatory variables, $\delta 0$ is a vector of unknown coefficients and $\varepsilon \mathrm{t}$ is a random error term. In this model elements of $z_{\mathrm{t}}$ may be correlated with the error term $\varepsilon$. In case of the existence of endogenous variables in $\mathrm{z}_{\mathrm{t}}$, the least squares estimator of $\delta 0$ is biased and inconsistent. Related to the model, a $\mathrm{K} \times 1$ vector of instrumental variables $x t$ is assumed that many contain elements of zt. Let wt represent the vector of unique and non-constant elements of $\{\mathrm{yt}, \mathrm{zt}, \mathrm{xt}\}$. It is assumed that $\{\mathrm{wt}\}$ is a stationary and ergodicstochastic process.

\subsection{Testing the Determinants of Firm's Value}




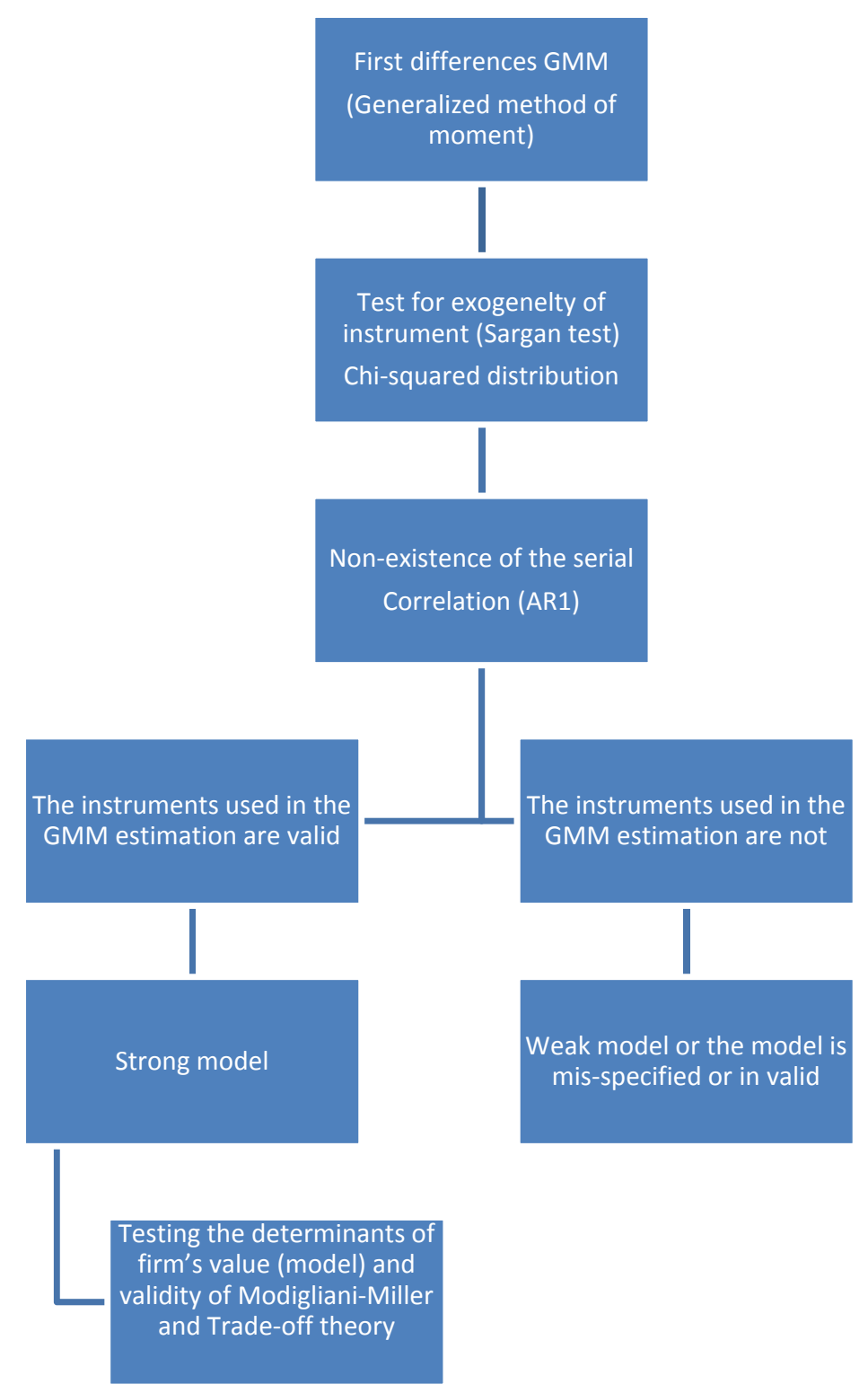

Figure 1. Generalized Method of Moments (Framework).

The instrumental variables xt satisfy the set of $\mathrm{K}$ orthogonality conditions

$$
\mathrm{E}\left[\mathrm{g}_{\mathrm{t}}\left(\mathrm{w}_{\mathrm{t}}, \delta 0\right)\right]=\mathrm{E}\left[\mathrm{x}_{\mathrm{t}} \varepsilon_{\mathrm{t}}\right]=\mathrm{E}\left[\mathrm{x}_{\mathrm{t}}\left(\mathrm{y}_{\mathrm{t}}-\mathrm{z}_{\mathrm{t}} \delta 0\right)\right]=0 \ldots \ldots \ldots
$$

where: $\mathrm{g}_{\mathrm{t}}\left(\mathrm{w}_{\mathrm{t}}, \delta 0\right)=\mathrm{x}_{\mathrm{t}} \varepsilon_{\mathrm{t}}=\mathrm{x}_{\mathrm{t}}\left(\mathrm{y}_{\mathrm{t}}-\mathrm{z}_{\mathrm{t}} \delta 0\right)$. Expanding (2), gives the relation

$$
\Sigma x y=\Sigma x z \delta 0 \ldots \ldots
$$

where: $\Sigma \mathrm{xy}=\mathrm{E}[\mathrm{xtyt}]$ and $\Sigma \mathrm{xz}=\mathrm{E}$ [xtz0t]. For identification of $\delta 0$, it is required that the $\mathrm{K} \times \mathrm{L}$ matrix $\mathrm{E}[\mathrm{xtz} 0 \mathrm{t}]=$ $\Sigma x z$ be of full rank L. Note, if $\mathrm{K}=\mathrm{L}$, then $\Sigma \mathrm{xz}$ is invertible and $\delta 0$ may be determined using $\delta 0=\Sigma-1 \mathrm{xz} \Sigma \mathrm{xy}$

A necessary condition for the identification of $\delta 0$ is the order condition

$$
\mathrm{K} \geq \mathrm{L}
$$

Above equation simply states that the number of instrumental variables must be greater than or equal to the number of explanatory variables. If $\mathrm{K}=\mathrm{L}$ then $\delta 0$ is said to be (apparently) just identified; if $\mathrm{K}>\mathrm{L}$ then $\delta 0$ is said to be (apparently) over-identified; if $\mathrm{K}<\mathrm{L}$ then $\delta 0$ is not identified.

To solve the problem of endogeneity of independent and explanatory variables, a two-step GMM method is used to control the correlation error over time that is, mitigating the effect of orthogonality conditions on errors, and 
heteroskedasticity across firms. Observed and unobserved firm-specific determinants determine the optimal capital structure. These firm and time specifics do changes on capital structure and the optimal leverage point. Depending on the determinants of capital structure, the following GMM model is developed:

$$
Y^{*}{ }_{i t}=\quad{ }_{0}+\sum_{k} \beta_{k \chi k \mathrm{kit}+} \quad i+\quad t+\quad i t \ldots \ldots \ldots \ldots
$$

Where: $\mathrm{Y}^{*}=$ the dependent variable

$\mathrm{i}=1, \ldots \ldots, \mathrm{N}$.

Firm-specific characteristics are measured by $\sum \mathrm{k} \beta \mathrm{k} \mathrm{X} \mathrm{X}_{\mathrm{k}}$, the result of it varies from time to time and from firm to other.

$\alpha_{\mathrm{i}}$ is the unobserved firm- specific effect,

$\alpha_{t}$ captures the time effect.

The lagged values of the dependent variable of the GMM model are examined to evaluate the consistency and the validity of the other explanatory variables. The error terms must not exhibit any serial correlation. The diagnostic tests that evaluate the validity of the GMM panel data model are (1) Test of exogeneity of instruments; (Sargan test) measured via Chi- squared distribution (2) Non-existence of the serial correlation AR1 \& AR2.

Serial correlation is often observed in time series data, but not in cross-section. Due to this limitation, the panel data approach is recommended. In order to avoid the problem of serial correlation, the first and second order serial correlation test is conducted. The AR1 and AR2 must provide a negative significant results and no evidence of second order autocorrelation. The error is assumed to be independent of its past; it has no memory of its past values. See equations 6, 7, 8 below.

Error Term has a mean of zero:

$$
\mathrm{E}(\mathrm{e})=0 \rightarrow \mathrm{E}(\mathrm{y})=\mathrm{b} 1+\mathrm{b} 2 \mathrm{x}
$$

Error term has constant variance:

$$
\operatorname{Var}(\mathrm{e})=\mathrm{E}(\mathrm{e} 2)=\sigma 2
$$

Error term is not correlated with itself (no serial correlation):

$$
\operatorname{Cov}(\text { ei,ej })=E(\text { eiej })=0 \quad i \neq j \quad \ldots \ldots \ldots \ldots
$$

The autocorrelation coefficient must lie between -1 and $1:-1<\rho<1$, Anything outside this range is unstable and unacceptable good for economic models.

The Sargan test is proposed by John Denis Sargan in 1958, sometimes called the Hansen test or J-test. It is used to examine the exogeneity of the instruments and their consistency. It is aimed at exploring variables and finding if they are uncorrelated to some sets of residual. If the Sargan test is not valid, the model is classified as weak. Under the null-hypotheses the chi square is employed test the overall validity of the instruments and the existence of over-identifying restrictions. The degrees of freedom are found by calculating the difference between the number of instruments and the number of regressors. The GMM is used to generate consistent and efficient estimators of the parameters and study. That consistency is not achieved if the error term exhibits serial correlation.

\section{Empirical Findings}

All of the datasets, namely closing price (CP), earnings per share (EPS), Debt/Equity ratio (DE) and dividend per share (DPS) were extracted from Dynaquest publication and analysed by SAS Program. In order to get the statistical results of GMM, the data were coded into SAS program and analyzed. The results of the panel GMM2 are reported below.

The PANEL Procedure

Pooled (OLS) Estimates

Dependent Variable: lcp (closing price) 
Table 2 .

\begin{tabular}{ll}
\hline Model Description & Pooled \\
Estimation Method & 14 \\
\hline Number of Cross Sections & 6 \\
Time Series Length & 6 \\
\hline
\end{tabular}

Table 3.

\begin{tabular}{llll}
\hline Fit Statistics & & & \\
\hline SSE & 34.4417 & DFE & 74 \\
MSE & 0.4654 & Root MSE & 0.6822 \\
R-Square & 0.6402 & & \\
\hline
\end{tabular}

Table 4.

\begin{tabular}{|c|c|c|c|c|c|c|}
\hline \multicolumn{7}{|c|}{ Parameter Estimates } \\
\hline \multirow{2}{*}{\multicolumn{7}{|c|}{$\begin{array}{l}H_{0} \text { : Absence of significant relationship between dependent variable and independent variable. } \\
H_{1} \text { : Presence of significant relationship between dependent variable and independent variable. }\end{array}$}} \\
\hline & & & & & & \\
\hline Variable & DF & Estimate & Error & t Value & $\operatorname{Pr}>|\mathbf{t}|$ & Label \\
\hline Intercept & 1 & 0.156178 & 0.1888 & 0.83 & 0.4109 & Intercept \\
\hline EPS & 1 & +0.062316 & 0.0131 & 4.77 & $<.0001^{*}$ & Earnings per share \\
\hline $\mathrm{DE}$ & 1 & +0.402612 & 0.1637 & 2.46 & $0.0162 *$ & Debt equity ratio \\
\hline DPS & 1 & +0.148704 & 0.0266 & 5.60 & $<.0001 *$ & Dividend per share \\
\hline
\end{tabular}

*significant at $5 \%$ level.

Pooled OLS is adopted here to provide the base-line analysis. Looking at the statistical results from pooled OLS (Table 4), it is evident that EPS, DE and DPS are statistically significant in influencing the firm's value as proxied by individual firm's closing price. Interestingly, the parameter estimate for each explanatory variable is positive indicating direct relationship firm's value and its explanatory variables.

The PANEL Procedure

GMM: First Differences Transformation

Dependent Variable: lcp (lagged closing price)

Table 5.

\begin{tabular}{ll}
\hline Model Description & GMM2 \\
Estimation Method & 14 \\
\hline Number of Cross Sections & 6 \\
Time Series Length & 2 \\
Estimate Stage & 5 \\
Maximum Number of Time Periods (MAXBAND) & 5 \\
\hline
\end{tabular}

Table 6.

\begin{tabular}{llll}
\hline Fit Statistics & & & \\
\hline SSE & 17.3810 & DFE & 45 \\
MSE & 0.3862 & Root MSE & 0.6215 \\
\hline
\end{tabular}

The result of the panel procedures via GMM shows that the number of companies in the analysis is now just fourteen instead of the initial eighteen. The size of time-series data remains 6 , from year 2010-2015. The results of Fit Statistics in Table 6 explain the goodness-of-fit statistics reported to measure how well different models fit the data. The value of SSE closer to 0 indicates that the model has a smaller random error component, and also the fit will be more useful for prediction. However, this is not suitable to do prediction as the value is greater than 0 . Hence, it applies to MSE, DFE, and Root MSE, where the value closer to 0 has greater potential for prediction. 
Table 7.

\begin{tabular}{lll}
\hline $\begin{array}{l}\text { Sargan Test } \\
\text { DF }\end{array}$ & Statistic & Prob $>$ ChiSq \\
\hline 5 & 9.93 & 0.0772 \\
\hline
\end{tabular}

The Sargan test (Table 7) is a test of the validity of instrumental variables. It is a test of the over identifying restrictions in a statistical model. The hypothesis testing on the Sargan test specifies that the instrumental variables are uncorrelated to some set of residuals, and therefore they are accepted as valid and credible instruments. From the diagnostic test, the null hypothesis is accepted which confirms that the instrument variables are valid.

Table 8

\begin{tabular}{|c|c|c|c|c|c|}
\hline \multicolumn{6}{|c|}{$\begin{array}{l}\mathrm{H}_{0} \text { : Absence of significant relationship between dependent variable and independent variable. } \\
\mathrm{H}_{1} \text { : Presence of significant relationship between dependent variable and independent variable. }\end{array}$} \\
\hline Variable & DF & Estimate & Error & t Value & $\operatorname{Pr}>|\mathbf{t}|$ \\
\hline Intercept & 1 & 0.075622 & 0.0816 & 0.93 & 0.3587 \\
\hline Lcp_1 & 1 & 0.157671 & 0.2181 & $0.72^{\text {ns }}$ & 0.4735 \\
\hline LDE & 1 & -0.26024 & 0.42223 & $-0.62^{\text {ns }}$ & 0.5408 \\
\hline LEPS & 1 & 0.060881 & 0.0675 & $0.90^{\mathrm{ns}}$ & 0.3716 \\
\hline LDPS & 1 & 0.103826 & 0.1302 & $0.80^{\mathrm{ns}}$ & 0.4292 \\
\hline
\end{tabular}

ns $=$ not significant.

Parameter estimation is a discipline that provides measures for the efficient use of data for aiding in mathematical modeling of phenomena and the estimation of constants appearing in the model. It can thus be visualized as a study of inverse problems (Zhang, 2004). The coefficient for DE is -0.26024 . For every unit increase in D/E, a -0.26024 drop in price is predicted, holding all other variables constant. Furthermore, the coefficient for EPS is 0.060881. Therefore, for every unit increase in EPS the price is expected to increase 0.060881 times, while holding all other variables constant. However, from the p-values reported in Table 8, none of the explanatory variable is significant in influencing the firm's value, including the lag one closing price (Lcp). It is worthy to note that these findings support the efficient market hypothesis at semi-strong level. The published information on companies such as their EPS and DPS are immaterial in influencing their future values.

Table 9.

\begin{tabular}{|c|c|c|}
\hline \multicolumn{3}{|c|}{$\begin{array}{l}\mathrm{H}_{0} \text { : There is no serial correlation or autocorrelation on residuals. } \\
\mathrm{H}_{1} \text { : Serial correlation is found on residuals. }\end{array}$} \\
\hline Lag & Statistic & Pr $>$ Statistic \\
\hline 1 & -1.21 & 0.8877 \\
\hline
\end{tabular}

$\mathrm{AR}(\mathrm{m})$ test is a representation of a type of random process; as such, it describes certain time-varying processes in nature. The autoregressive model specifies that the output variable depends linearly on its own previous values. It is a special case of the more general ARMA model of time series. The p-value of AR (m) test is 0.8877 , and it is greater than $\alpha$ of $5 \%$. This implies absence of autocorrelation problem.

Table 10 . 


\begin{tabular}{|c|c|c|c|c|c|c|}
\hline \multicolumn{7}{|c|}{ The MEANS Procedure: Descriptive Statistics } \\
\hline Variable & Label & $\mathrm{N}$ & Mean & Std Dev & Minimum & Maximum \\
\hline $\mathbf{C P}$ & Closing price $(\mathrm{RM})$ & 78 & 1.7596154 & 1.1149252 & 0.2900000 & 5.3600000 \\
\hline DE & Debt equity & 78 & 0.6216667 & 0.4819129 & 0.0100000 & 1.8600000 \\
\hline EPS & $\begin{array}{l}\text { Earnings per share } \\
\text { (Cent) }\end{array}$ & 78 & 11.6243718 & 7.4339695 & 0.0010000 & 31.4000000 \\
\hline DPS & $\begin{array}{l}\text { Dividend per share } \\
\text { (Cent) }\end{array}$ & 78 & 4.2282564 & 3.6163843 & 0.0010000 & 15.0000000 \\
\hline
\end{tabular}

The means procedure explains the descriptive statistics of the given data sets. Based on Table 10, the average DE is 0.6216 and this is considered relatively low for construction industry. It is interesting to note that the EPS is moderately high with an average of 11.62 cents. The average DPS of 4.22 cents is deemed low and perhaps this could be due to low dividend pay-out ratio as companies in construction industry prefer to capitalize their net profits.

\section{Conclusion}

This paper aims to develop in-depth understanding on the relationship between firm's value and its capital structure which is generally reflected by profit and leverage as the determinants of the company's performance. The study involves a total of 14 companies from construction sector and each company's value (firm's value) is measured by its closing prices, while the company's profits and leverage are provided by EPS and DE ratio respectively. From the findings, it can be concluded that there is no significant relationship between the firm's value and its DE and EPS. It is shocking to observe an absence of any relationship with Trade-Off theory and Modigliani-Miller theory. Perhaps, future research should consider incorporating more companies in the analysis. From the Sargan test, all the instrumental variables are uncorrelated to some set of residuals, and therefore they are proven to be acceptable valid instruments. This is confirmed from the acceptance of null hypothesis. The result of AR (m) confirms the absence of autocorrelation in the estimation model. As a whole, the empirical findings from the study on construction sector at Bursa Malaysia do not support the essence of Modigliani-Miller and Trade-Off theories.

\section{References}

Barclay, M., Smith, C. W., \& Watts, R. L. (1995). The Determinants of Corporate Leverage and Dividend $\begin{array}{llllll}\text { Policies. Journal of Applied } & \text { Corporate }\end{array}$ https://doi.org/10.1111/j.1745-6622.1995.tb00259.x

Brigham, E. \& Gapenski, L. (1996). Financial Management. Dallas: The Dryden Press.

Coricelli, F., Driffield, N., Pal, S., \& Roland, I. (2011). Excess Leverage and Productivity Growth in Emerging Economies: is there a Threshold Effect? CEPR Discussion Papers 7617, C.E.P.R. Discussion Papers.

Ehrhardt, M. C. \& Brigham, E. F. (2006). 'Financial Management: Theory and Practice,' New York: Prentice Hall.

Gleason, K. C., Mathur L. K. \& Mathur, I. (2000). The Interrelationship between Cultures, Capital Structure, and Performance: Evidence from European Retailers," Journal of Business Research, 50(2), 185-91. https://doi.org/10.1016/S0148-2963(99)00031-4

Hadlock, C. J., \& James, C. M. (2002). Do Banks Provide Financial Slack? Journal of Finance, 57(3), 1383-420. https://doi.org/10.1111/1540-6261.00464

Huyghebaert, N. (2006). On the Determinants and Dynamics of Trade Credit Use: Empirical Evidence from Business Start-Ups. Journal of Business Finance \& Accounting, 33, 305-328. https://doi.org/10.1111/j.1468-5957.2006.001364.x

Kovenock, D., \& Phillips, G. M. (1995). Capital Structure and Product-Market Rivalry: How Do We Reconcile Theory and Evidence? American Economic Review, 85(2), 403-408. https://doi.org/10.1093/rfs/10.3.767

Kovenock, D., \& Phillips, G. M. (1997). Capital Structure and Product Market Behavior: An Examination of Plant Exit and Investment Decisions. Review of Financial Studies, 10(3), 767-803. https://doi.org/10.1016/S1044-0283(97)90010-7

Krishnan, V. S., \& Moyer, C. R. (1997). Performance, Capital Structure and Home Country: An Analysis of 
Asian Corporations. Global Finance Journal, 8(1), 129-143.

Majumdar, S. K. \& Chhibber, P. (1997). Capital Structure and Performance: Evidence from a Transition Economy on an Aspect of Corporate Governance. Public Choice, 98(3-4), 287-305. https://doi.org/10.1023/A:1009825432146

Maksimovic, V., Stomper, A. \& Zechner, J. (1999). Capital Structure, Information Acquisition and Investment Decisions in an Industry Framework. European Finance Review, 2, 251-271.

Myers, S. C. (2001). Capital Structure. Journal of Economic Perspectives, 15(2), 81-102. https://doi.org/10.1257/jep.15.2.81

Noe, T. H. (1988). Capital Structure and Signaling Game Equilibria. Review of Financial Studies, 1(4), 331-355. https://doi.org/10.1093/rfs/1.4.331

Rao, N. V., Al-Yahyaee, K. H. M., \& Syed, L. A. M. (2007). Capital Structure and Financial Performance: Evidence from Oman. Indian Journal of Economics and Business, 7(2), 1-14.

Roden, D. M., \& Lewellen, W. G. (1995). Corporate Capital Structure Decisions: Evidence from Leveraged Buyouts. Financial Management, 24(2), 76-87. https://doi.org/10.2307/3665536

Ross, S. A. (1977). The Determination of Financial Structure: The Incentive Signaling Approach. Bell Journal of Economics, 8(1), 23-40. https://doi.org/10.2307/3003485

Sharma, A. K. (2006). 'Financial Leverage and Firm's Value: A Study of Capital Structure of Selected Manufacturing Sector Firms in India,' The Business Review, Cambridge, 6(2), 70-76.

Titman, S. \& Wessels, R. (1988). The Determinants of Capital Structure Choice. Journal of Finance, 43, 1-19. https://doi.org/10.1111/j.1540-6261.1988.tb02585.x

Zeitun, R. \& Tian, G. G. (2007). Capital Structure and Corporate Performance: Evidence from Jordan. Australasian Accounting Business and Finance Journal, 1(4), 40-61.

\section{Copyrights}

Copyright for this article is retained by the author(s), with first publication rights granted to the journal.

This is an open-access article distributed under the terms and conditions of the Creative Commons Attribution license (http://creativecommons.org/licenses/by/4.0/). 